\title{
Analisis PAD dan Dana Perimbangan Terhadap Kinerja Keuangan Pemda Se-Jawa Barat
}

\author{
Putri Puspita Ayu \\ Universitas Swadaya Gunung Jati \\ Puspitaayu12@gmail.com
}

\begin{abstract}
The research is to find out and analyze the contribution of Original income Equalization Funds against the region and the financial performance of local Government Counties and the city of se-West Java province.

Hypothesis testing in this study using multiple regression analysis (Multiple Regression) on the grounds that its independent variable more than one. This analysis is used to determine the relationship between financial performance areas with independent variables (the original Revenue Equalization Fund and regional). To know the influence between independent variables with the performance levels of local government then performed testing of hypothesis testing research on the variables with the determination coefficient and t-test.

Linear regression analysis of the barganda equation $\mathrm{KKPD}=1.452+0,561 \mathrm{PAD}-0,171 \mathrm{DP}+\mathrm{e}$. Whereas determinasinya coefficients (R2) of $25.3 \%$. based on the research results obtained the conclusion that Equalization Fund of PAD effect partially against the financial performance of local government.
\end{abstract}

\begin{abstract}
Abstrak
Penelitian ini adalah untuk mengetahui dan menganalisis kontribusi Pendapatan Asli Daerah dan Dana Perimbangan terhadap Kinerja Keuangan Pemerintah Daerah Kabupaten dan Kota seProvinsi Jawa Barat. Pengujian hipotesis dalam penelitian ini menggunakan analisis regresi berganda (Multiple Regression) dengan alasan bahwa variabel independennya lebih dari satu. Analisis ini digunakan untuk menentukan hubungan antara kinerja keuangan daerah dengan variabel-variabel independen (Pendapatan Asli Daerah dan Dana Perimbangan). Untuk mengetahui pengaruh antara variabel-variabel independen dengan tingkat kinerja pemerintah daerah maka dilakukan pengujian pengujian hipotesis penelitian terhadap variabel-variabel dengan uji t dan koefisien determinasi. Persamaan analisis regresi linier barganda KKPD =1,452 $+0,561 \mathrm{PAD}-0,171 \mathrm{DP}+$ e. Sedangkan nilai koefisien determinasinya $\left(\mathrm{R}^{2}\right)$ sebesar $25.3 \%$. berdasarkan hasil penelitian diperoleh kesimpulan bahwa PAD dan dana perimbangan berpengaruh secara parsial terhadap Kinerja Keuangan Pemerintah Daerah.
\end{abstract}

Kata Kunci: Pendapatan Asli Daerah, Dana Perimbangan, Kinerja Keuangan Pemerintah Daerah 


\section{PENDAHULUAN}

Ditetapkannya Undang-Undang no 32 tahun 2004 memberikan kewenangan kepada pemerintah daerah dalam mengatur semua pengelolaan keuangan daerah demi terciptanya pembangunan yang menyeluruh, sehingga bisa meningkatkan pelayanan dan kesejahteraan bagi semua masyarakat di daerah tersebut. Dalam rangka meningkatkan pembangunan daerah, desentralisasi diyakini dapat menjadi salah satu alat untuk meningkatkan kemandirian daerah. Dengan diterapkannya desentralisasi, maka pemerintah daerah diharapkan mampu mengoptimalkan Pendapatan Asli Daerahnya guna membiayai pembangunan.

Mengoptimalkan pendapatan asli daerah bisa dilakukan dengan berbagai cara, diantaranya mengidentifikasi potensi dan sumber-sumber daya yang dimiliki daerah, khususnya sumber-sumber pendapatan dalam rangka pembiayaan pembangunan daerah. Dengan semakin besar pelimpahan wewenang dari pemerintah pusat ke daerah membuat pemerintah daerah harus berupaya untuk lebih meningkatkan Pendapatan Asli Daerahnya.

Dalam desentralisasi, pemberian wewenang kepada pemerintah daerah tidak berarti pemerintah pusat lepas tangan, salah satu bentuk peran pemerintah pusat yaitu lewat dana perimbangan yang berkontribusi pada APBD. Dalam Undang-undang nomor 33 tahun 2004 Dana Perimbangan adalah pendapatan pemerintah daerah yang diterima dari pemerintah pusat dan diperuntukkan untuk membiayai pengeluaran daerah. Pemberian dana perimbangan kepada pemerintah daerah memperhatikan potensi, keadaan, dan kebutuhan daerah masing-masing sehingga tercipta pembagian keuangan yang merata, proporsional, efektif, dan efisien.

Penelitian ini diharapkan mampu menjadi masukan bagi pemerintah daerah untuk meningkatkan kinerja keuangan pada khususnya dan kinerja secara keseluruhan pada umumnya. Berdasarkan pemaparan diatas, maka penulis tertarik untuk melakukan penelitian dengan judul "Analisis Kontribusi Pendapatan Asli Daerah (PAD) dan Dana Perimbangan Terhadap Kinerja Keuangan Pemerintah Daerah Kabupaten dan Kota se-Provinsi Jawa Barat Tahun 2014-2015".

Berdasarkan pemaparan sebelumnya maka tujuan dari penelitian ini adalah untuk mengetahui dan menganalisis kontribusi Pendapatan Asli Daerah dan Dana Perimbangan terhadap Kinerja Keuangan Pemerintah Daerah Kabupaten dan Kota se-Provinsi Jawa Barat. 


\section{TINJAUAN PUSTAKA dan PENGEMBANGAN HIPOTESIS}

\section{Pengukuran Kinerja Keuangan Pemerintah Daerah}

Pengukuran kinerja pemerintah adalah salah satu fungsi manejemen dalam rangka mendorong peningkatan kualitas pengambilan keputusan dan akuntabilitas, sehingga dapat digunakan untuk mengukur tingkat keberhasilan program pemerintah serta membandngkan kesesuaian antara tujuan dan implementasinya (Whitaker). Hal ini, sejalan dengan pemaparan Simons (1995) yang menyatakan pengukuran kinerja merupakan salah satu cara yang digunakan dalam menilai kemajuan yang telah dicapai dibandingkan dengan tujuan yang telah ditetapkan sebelumnya.

Analisis rasio digunakan sebagai salah satu indicator dalam menganalisis kinerja pengelolaan keuangan daerah. Analisis rasio yang digunakan oleh sektor public dalam hal ini pengelolaan keuangan pemerintah daerah berbeda dengan perhitungan rasio yang digunakan dalam perusahaan swasta. Indikator kinerja keuangan mencakup dua hal yaitu tujuan yang dapat diukur dengan rasio dan peningkatan disetiap target kinerja. Setiap program pemerintah, harus memiliki tujuan yang jelas dan juga target keberhasilannya agar dapat diukur keberhasilan programnya.

\section{Analisis Rasio Keuangan Berdasarkan Anggaran Pendapatan Belanja Daerah}

Salah satu cara untuk menganalisis laporan keuangan, adalah dengan menggunakan analisis rasio. Rasio yang dapat digunakan dalam mengukur kinerja pemerintah daerah diantaranya adalah sebagai berikut:

\section{Rasio Kemandirian Keuangan Daerah}

Kemandirian keuangan daerah menggambarkan tingkat kemampuan daerah unuk mengelola sendiri kegiatan pemerintahan daerahnya guna meningkatkan pembangunan dan pelayanan kepada manyaraka sebagai timbal balik atas pembayaran pajak dan retribusi yang dibayarkan oleh masyarakat kepada pemerintah daerah. Rasio kemandirian keuangan daerah dapat diukur melalui perbandingan pendapatan asli daerah dengan bantuan pemerintah pusat, diantaranya Dana Alokasi Umum (DAU) maupun Dana Alokasi Khusus (DAK). Semakin tinggi 
rasio kemandirian berarti daerah dianggap semakin mampu untuk membiayai pembangunannya sendiri, demikian pula sebaliknya. Rasio kemudian dapat diformulasikan sebagai berikut.

$$
\text { rasio kemandirian }=\frac{\text { pendapatan asli daerah (PAD) }}{\text { bantuan pemerintah pusat atau provinsi dan pinjaman }}
$$

\section{Rasio Efektivitas dan Efisiensi PAD}

Rasio efektivitas menggambarkan keberhasilan pemerintah daerah untuk merealisasikan PAD sesuai dengan target yang telah ditetapkan. Tingginya rasio efektivitas, menggambarkan pemerintah daerah mampu dalam mencapai target penerimaan PAD. Pemerintah daerah dikatan efektif dalam pengelolaan keuangan jika rasio efektivitas mencapai nilai lebih dari $100 \%$.

rasio efektivitas $=\frac{\text { realisasi penerimaan PAD }}{\text { target penerimaan PAD ditetapkan berdasarkan potensi riil daerah }}$

agar keberhasilan pemerintah daerah lebih terukur, maka perlu dibandingkan antara rasio efektivitas dengan efisiensi. Rasio efisiensi adalah rasio yang membandingkan antara besarnya pengeluaran untuk memperoleh pendapatan asli daerah dengan realisasi pendapatan yang diterima. Pemerintah daerah dikatakan efisien dalam pengelolaan keuangan jika rasio efesiensinya dibawah $100 \%$.

$$
\text { rasio efisiensi }=\frac{\text { biaya yang dikeluarkan untuk memungut PAD }}{\text { realisasi penerimaan daerah }}
$$

Contoh pengeluaran untuk memungut PAD adalah seluruh biaya yang dikeluarkan oleh setiap instansi daerah dalam rangka memungut PAD.

\section{Pendapatan Asli Daerah}

Pendapatan asli daerah merupakan semua potensi sumber daya ekonomi asli daerah yang dapat dijadikan penerimaan daerah. Pasal 157 Undang-Undang No. 32 Tahun 2004 tentang Pemerintahan Daerah memaparkan bahwa PAD dapat dibagi menjadi empat kelompok, yaitu :

1. Pajak daerah, yaitu pungutan yang dilakukan oleh pemerintah daerah berdasarkan peraturan perundang-undangan yang berlaku ditetapkan melalui peraturan daerah. Pungutan ini berlaku untuk wajib pajak seperti orang atau badan usaha dan benda bergerak/tidak bergerak, seperti perhotelan, rumah makan, pajak hiburan, pajak reklame, dll. 
2. Hasil retribusi daerah, yaitu pungutan langsung yang dikenakan atas pemakaian suatu jasa/fasilitas umum milik daerah seperti retribusi Kebersihan, pemakaman, pengolahan limbah, dll.

3. Hasil pengelolaan kekayaan daerah yang dipisahkan, yaitu pendapatan daerah yang berasal dari perusahaan milik daerah/BUMD, bagian laba BUMN, bagian laba perusahaan milik swasta.

4. Lain-lain PAD yang sah, yaitu pendapatan daerah yang dihasilkan dari penjualan aset daerah, jasa giro, pendapatan bunga, dll.

\section{Dana Perimbangan}

Dana Perimbangan adalah pemberian dana dari pemerintah pusat kepada pemerintah daerah untuk melaksanakan pembangunan daerah agar desentralisasi dapat tercapai. Tujuan diberikannya dana perimbangan adalah: 1. Sebagai upaya untuk pemerataan pembangunan. 2 . Sebagai upaya untuk melakukan efisiensi biaya otonomi daerah.

Pembagian dana perimbangan yang tidak merata, dapat berdampak pada ketergatungan pemerintah daerah kepada pemerintah pusat, yang sebeneranya peruntukan dana perimbangan hanya sebagai stimulus untuk meningkatkan sumber PAD.

Berdasarkan Undang undang no 33 tahun 2004; Dana perimbangan dibagi menjadi, (1) Dana Bagi Hasil, (2) Dana Alokasi Umum, dan (3) Dana Alokasi Khusus.

\section{Dana Bagi Hasil}

Dana Bagi Hasil terdiri dari Bagi Hasil Pajak dan Bagi Hasil Bukan Pajak (SDA) Dana bagi hasil pajak bersumber dari Pajak Penghasilan (PPh), Pajak Bumi dan Bangunan (PBB), serta Bagian Perolehan Hak atas Tanah dan Bangunan (BPHTB). Sedangkan, Dana Bagi Hasil Bukan Pajak terdiri dari minyak bumi, gas alam, pertambangan umum, kehutanan, dan perikanan. 


\section{Dana Alokasi Umum (DAU)}

Dana alokasi umum yaitu dana yang diterima dari pemerintah pusat yang ditujukan untuk membiayai pengeluaran agar tercapai pemerataan pembangunan. Besarnya Dana alokasi khusus untuk propinsi dan kabupaten/kota adalah 10\% dan 90\% dari Dana alokasi khusus.

\section{Dana Alokasi Khusus (DAK)}

Pengertian DAK dalam UU No. 33 Tahun 2004 yaitu dana APBN yang diperuntukan membiayai kebutuhan khusus. Kebutuhan khusus tersebut contohnya kebutuhan tak terduga.

\section{Kerangka Pemikiran}

Pemerintah daerah harus selalu meningkatkan kemampuanya untuk menghasilkan keuangan daerah melalui penggalian pendapatan asli daerah atau PAD. harus terus dipacu pertumbuhannya karena kenaikan Pendapatan Asli Daerah (PAD) ini akan sangat berpengaruh pada kinerja pemerintah daerah. Kinerja ini dapat dilihat melalui sasaran yang telah tercapai dalam pelaksanaan pembangunan dan pelayanan kepada masyarakat melalui pemanfaatan PAD (Pajak Daerah, Retribusi Daerah, Hasil perusahaan dan kekayaan daerah, dan Lain-Lain Pendapatan yang sah). Pendapatan Asli Daerah (PAD) merupakan tulang punggung pembiayaan daerah. Maka dari itu, pesatnya pembangunan suatu daerah sangat ditunjang oleh kemampuan pemerintah daerah untuk menggali PADnya.

Bila APBD lebih banyak dibiayai oleh PAD, berarti ketergantungan pemerintah daerah terhadap dana dari pemerintah pusat semakin kecil. Pemerintah daerah lebih leluasa dalam menggunakan PAD dibandingkan dengan dana yang diberikan pemerintah pusat.

Dana Perimbangan adalah dana yang diberikan pemerintah pusat kepada pemerintah daerah guna membiayai pembangunan daerah agar desentralisasi dapat berjalan dengan baik dan merata sehingga tidak terjadi ketimpangan fiscal antar daerah. Semakin besar bantuan dana dari pemerintah pusat kepada daerah, menjadikan daerah semakin bergantung secara finansial pada pemerintah pusat. 


\section{METODE PENELITIAN}

\section{Jenis Penelitian}

Dalam penelitian ini akan mencari kontribusi Pendapatan Asli Daerah (PAD) dan Dana Perimbangan terhadap Kinerja Keuangan Pemerintah Daerah. Penelitian ini menggunakan data sekunder. Data sekunder diperoleh dari Laporan Hasil Pemeriksaan BPK Perwakilan Jawa Barat. Penelitian ini menggunakan Pendapatan Asli Daerah (X1) dan Dana Perimbangan (X2) sebagai variabel independen dan Kinerja Keuangan Pemerintah Daerah (Y) sebagai variabel dependen.

\section{Operasionalisasi Variabel}

Variabel terikat dalam penelitian ini adalah kinerja keuangan pemerintah daerah $(\mathrm{Y})$, sedangkan variabel independenya adalah Pendapatan Asli Daerah dan Dana Perimbangan. Definisi operasional dan metode pengukuran variabel penelitian ini adalah:

Kinerja Keuangan Pemerintah Daerah

$$
\begin{aligned}
& \text { rasio efektivitas }=\frac{\text { realisasi penerimaan PAD }}{\text { target penerimaan PAD ditetapkan berdasarkan potensi riil daerah }} \\
& \text { rasio efektivitas }=\frac{\text { realisasi penerimaan PAD }}{\text { target penerimaan PAD ditetapkan berdasarkan potensi riil daerah }}
\end{aligned}
$$

Pendapatan Asli Daerah

$$
\begin{aligned}
\text { PAD }= & \text { Pajak Daerah }+ \text { Retribusi Daerah }+ \text { Hasil } \\
& \text { Pengelolaan Kekayaan Daerah yang } \\
& \text { dipisahkan }+ \text { Lain-lain PAD yang sah }
\end{aligned}
$$

Dana Perimbangan

$\begin{aligned} \text { Dana Perimbangan }= & \text { Dana Bagi Hasil Pajak + Dana Bagi Hasil } \\ & \text { Bukan Pajak }+ \text { Dana Alokasi Umum + Dana } \\ & \text { Alokasi Khusus }\end{aligned}$




\section{Metode Analisis}

\section{Pengujian Hipotesis}

Pengujian hipotesis dalam penelitian ini menggunakan analisis regresi berganda (Multiple Regression) dengan alasan bahwa variabel independennya lebih dari satu. Analisis ini digunakan untuk menentukan hubungan antara kinerja keuangan daerah dengan variabel-variabel independen (Pendapatan Asli Daerah dan Dana Perimbangan).

Persamaan regresinya adalah sebagai berikut :

$$
Y=a+b 1(P A D)+b 2(D P)+e
$$

Dimana :

$\mathrm{Y} \quad=$ Kinerja Keuangan Pemerintah Daerah

PAD = Pendapatan Asli Daerah

$\mathrm{DP} \quad=$ Dana Perimbangan

Kemudian untuk mengetahui pengaruh antara variabel-variabel independen dengan tingkat kinerja pemerintah daerah maka dilakukan pengujian pengujian hipotesis penelitian terhadap variabel-variabel dengan pengujian dibawah ini :

a. Uji t

Uji t digunakan untuk menguji keterikatan variabel independent secara parsial dalam menjelaskan perilaku variabel dependen. Pengujian dilakukan dengan menggunakan tingkat signifikansi 0,05 $(\alpha=5 \%)$.

b. Koefisien Determinasi

Koefisien determinasi menunjukkan seberapa besar variabel independen mempengaruhi variabel dependen. Untuk regresi dengan variabel bebas lebih dari dua maka digunakan adjusted R2 sebagai koefisien determinasi. Koefisien determinasi untuk mengukur proporsi variasi dalam variabel dependen yang dijelaskan oleh regresi. Nilai R2 berkisar antara 0 sampai 1, apabila R2 $=0$ berarti tidak ada hubungan antara variabel Pendapapan Asli Daerah dan Dana Perimbangan 
dengan variabel Kinerja Keuangan Pemerintah Daerah, sedangkan jika R2 $=1$ berarti terdapat suatu hubungan yang sempurna.

\section{HASIL PENELITIAN dan PEMBAHASAN}

\section{Analisis Data dan Pembahasan}

Pada tabel di atas diperoleh nilai rata-rata (mean) variabel Kinerja Keuangan Pemerintah Daerah (KKPD) sebesar 0,9411 dengan standar deviasi sebesar 0,04974 sedangkan nilai minimum sebesar 0,81 dan nilai maximum 1,11. Dari tabel 1 juga dapat diketahui bahwa nilai rata-rata (mean) variabel Pendapatan Asli Daerah sebesar 155.174.518.033 dengan standar deviasi sebesar 137.910.299.688 sedangkan nilai minimum sebesar 77.798.000.000 dan nilai maximum 925.919.000.000. Sedangkan nilai rata-rata (mean) variabel Dana Perimbangan (DP) sebesar 876.423.065.574 dengan standar deviasi sebesar 227.347.423.111 sedangkan nilai minimum sebesar 387.037.000.000 dan nilai maximum sebesar 1.271.384.000.000.

\section{Hasil Pengujian Asumsi Klasik}

\section{Uji normalitas}

Berikut hasil uji normalitas menggunakan uji Kolmogorov-Smirnov :

Hasil uji Normalitas

One-Sample Kolmogorov-Smirnov Test

\begin{tabular}{|ll|l|}
\hline & & $\begin{array}{l}\text { Unstandardized } \\
\text { Residual }\end{array}$ \\
\hline $\mathrm{N}$ & Mean & 81 \\
Normal Parameters & $\mathrm{a}, \mathrm{b}$ & .0000000 \\
& $\begin{array}{l}\text { Std. Deviation } \\
\text { Absolute }\end{array}$ & .140 \\
& $\begin{array}{l}\text { Positive } \\
\text { Most Extreme Differences }\end{array}$ & .140 \\
Kolmogorov-Smirnov Z & Negative & -.063 \\
Asymp. Sig. (2-tailed) & .989 \\
& & .282 \\
\hline
\end{tabular}

a. Test distribution is Normal.

b. Calculated from data.

Sumber: Data sekunder yang diolah, 2017 
Hasil pengujian data menggunakan Uji Kolmogorov-Smirnov yang disajikan pada tabel tersebut menunjukkan nilai Asymp.Sig (2-tailed)> 0,05 yaitu sebesar 0,282 maka dapat disimpulkan bahwa data berdistribusi secara normal.

\section{Uji Multikolinieritas}

Berikut adalah hasil uji multikolinearitas dengan IBM SPSS Statistics 21 :

\section{Hasil Uji Multikolinieritas}

\section{Coefficients $^{\mathrm{a}}$}

\begin{tabular}{|ll|l|l|}
\hline \multicolumn{2}{|l|}{ Model } & \multicolumn{2}{|l|}{ Collinearity Statistics } \\
\cline { 3 - 4 } & & $\begin{array}{l}\text { Toleranc } \\
\mathrm{e}\end{array}$ & VIF \\
\hline \multirow{3}{*}{1} & (Constant) & & \\
& LOG10PAD & .822 & 1.216 \\
& LOG10DP & .790 & 1.265 \\
\hline
\end{tabular}

a. Dependent Variable: SM

Sumber : Data sekunder yang diolah, 2017

Hasil pengujian data yang disajikan pada tabel 4.7 menunjukkan bahwa Varian Inflation Factor (VIF) pada masing-masing variabel independen tidak ada satupun yang memiliki nilai VIF $\geq 10$. Nilai VIF Pendapatan Asli Daerah (X1) sebesar 1,216, dan DanaPerimbangan (X2) sebesar 1,265. Selain dilihat dari nilai VIF, untuk mengetahui ada tidaknya korelasi antar variabel independen dapat dilihat dari nilai tolerance. Pada tabel dapat dilihat bahwa nilai tolerance masing-masing variabel tidak ada yang memiliki nilai tolerance $\leq 0,10$. Pendapatan Asli DAerah (X1) sebesar 0,822, dan Dana Perimbangan (X2) sebesar 0,790. Dari perhitungan tersebut, disimpulkan bahwa tidak terjadi multikolinearitas diantara variabel-variabel independen dalam penelitian ini. 


\section{Uji Autokorelasi}

Berikut adalah hasil uji Durbin-Watson dengan IBM SPSS Statistics 21 :

\section{Hasil Uji Autokorelasi}

\section{Model Summary ${ }^{b}$}

\begin{tabular}{|l|l|l|l|l|l|}
\hline Model & $\mathrm{R}$ & R Square & $\begin{array}{l}\text { Adjusted R } \\
\text { Square }\end{array}$ & $\begin{array}{l}\text { Std. Error of } \\
\text { the Estimate }\end{array}$ & $\begin{array}{l}\text { Durbin- } \\
\text { Watson }\end{array}$ \\
\hline 1 & $.547^{\mathrm{a}}$ & .299 & .253 & .20624 & 2.246 \\
\hline
\end{tabular}

a. Predictors: (Constant), LOG10PAD, LOG10DP

b. Dependent Variable: LOG10KKPD

Sumber : Data sekunder yang diolah, 2017

Nilai DW 2,246 lebih besar dari batas (du) 1,6739 dan kurang dari $4-$ du $(4-1,6739=$ 2,3261), maka H0 diterima yang menyatakan bahwa tidak ada korelasi positif atau negatif sesuai dengan tabel keputusan $\mathrm{du}<\mathrm{d}<4-\mathrm{du}$ atau 1,6739 $<2,246<2,3261$ sehingga dapat disimpulkan model regresi linear dalam penelitian ini bebas dari autokorelasi.

\section{Uji Heteroskedastisitas}

Berikut adalah hasil uji park dengan IBM SPSS Statistics 21 pada tabel 4.10 :

\section{Hasil Uji Heteroskedastisitas}

\section{Coefficients $^{\mathrm{a}}$}

\begin{tabular}{|c|c|c|c|c|c|c|}
\hline \multirow{2}{*}{\multicolumn{2}{|c|}{ Model }} & \multicolumn{2}{|c|}{$\begin{array}{l}\text { Unstandardized } \\
\text { Coefficients }\end{array}$} & $\begin{array}{l}\text { Standardized } \\
\text { Coefficients }\end{array}$ & \multirow[t]{2}{*}{$\mathrm{t}$} & \multirow[t]{2}{*}{ Sig. } \\
\hline & & B & Std. Error & Beta & & \\
\hline \multirow{3}{*}{1} & (Constant) & 997 & .189 & & 5.277 & .000 \\
\hline & PAD & 1.712 & 1.506 & .175 & 1.137 & .261 \\
\hline & DP & -.709 & .910 & -.121 & -.780 & .440 \\
\hline
\end{tabular}

a. Dependent Variable: KKPD

Sumber : Data sekunder yang diolah, 2017

Berdasarkan hasil uji heteroskedastisitas yang ditampilkan pada tabel 4.10, dapat dilihat bahwa nilai signifikan pada masing-masing variabel memiliki nilai yaitu PAD (X1) sebesar 0,261, dan Dana Perimbangan (X2) sebesar 0,440, maka dapat disimpulkan bahwa tidak terjadi heteroskedastisitas. 


\section{Analisis Regresi Linier Berganda}

Berikut adalah hasil analisis regresi linier berganda dari Pendapatan Asli Daerah (X1), Dana Perimbangan(X2), dan Kinerja Keuangan Pemerintah Daerah (Y) dengan IBM SPSS Statistics 21:

\section{Hasil Uji Analisis Regresi Linier Berganda}

\section{Coefficients $^{\mathrm{a}}$}

\begin{tabular}{|cl|l|l|l|l|l|}
\hline \multicolumn{2}{|l|}{ Model } & \multicolumn{2}{|l|}{$\begin{array}{l}\text { Unstandardized } \\
\text { Coefficients }\end{array}$} & $\begin{array}{l}\text { Standardized } \\
\text { Coefficients }\end{array}$ & $\mathrm{t}$ & \multirow{2}{*}{ Sig. } \\
\cline { 2 - 5 } & $\mathrm{B}$ & Std. Error & Beta & & \\
\hline \multirow{2}{*}{1} & (Constant) & 1.452 & .400 & & 3.628 & .001 \\
& LOG10PAD & .561 & .260 & .315 & 2.160 & .036 \\
& LOG10DP & -.171 & .126 & -.201 & -1.350 & .018 \\
\hline
\end{tabular}

a. Dependent Variable: SM

Sumber : Data sekunder yang diolah, 2017

Berdasarkan hasil analisis regresi linier berganda yang di sajikan pada table, maka diperoleh persamaan regresi linier berganda sebagai berikut :

$$
\begin{aligned}
& \text { KKPD = 1,452 + 0,561PAD - 0,171DP + e } \\
& \text { Keterangan: } \\
& \text { KKPD = Kinerja Keuangan Pemerintah Daerah } \\
& \text { a = Konstanta } \\
& \text { b1,2,3 = koefisien regresi } \\
& \text { PAD = Pendapatan Asli Daerah } \\
& \text { DP = Dana Perimbangan } \\
& \text { e = error }
\end{aligned}
$$

Penjelasan dari persamaan regresi linier berganda adalah sebagai berikut :

1. Diketahui bahwa nilai konstanta sebesar 1,452 . Besaran nilai tersebut berarti jika variabelvariabel independen diasumsikan konstan atau sama dengan nol, maka variabel dependen yaitu kinerja keuangan pemerintah daerah sebesar 1,452. 
2. Nilai koefisien regresi variabel Pendapatan asli daerah (PAD) (X1) sebesar 0,561. Artinya jika variabel Pendapatan asli daerah (PAD) naik 1 satuan dan variabel lain diasumsikan konstan, maka Kinerja Keuangan Pemerintah Daerah akan mengalami kenaikan sebesar 0,561 satuan.

3. Nilai koefisien regresi variabel Dana Perimbangan (DP) (X2) sebesar -0,171. Artinya jika variabel Dana Perimbangan (DP) naik 1 satuan dan variabel lain diasumsikan konstan, maka struktur modal akan mengalami penurunan sebesar 0,171 satuan.

\section{Hasil Pengujian Hipotesis}

Pengujian hipotesis dalam penelitian ini dilakukan dengan uji statistik $\mathrm{t}$, uji statistik $\mathrm{f}$ dan koefisien determinasi. Berikut hasil pengujian hipotesis yang dilakukan dengan IBM SPSS Statistics 21:

\section{Uji Statistik t (parsial)}

Berdasarkan uji statistik t yang disajikan pada tabel, maka dapat disimpulkan bahwa hasil pengujian hipotesis pada masing-masing variabel adalah sebagai berikut :

\section{Pengujian pengaruh PAD terhadap Kinerja Keuangan}

Hasil uji hipotesis variabel risiko bisnis menggunakan tingkat signifikansi $\alpha=5 \%$ diperoleh p-value sebesar 0,036 dimana lebih kecil dari $\alpha$ 0,05 yang berarti hipotesis pertama $\left(\mathrm{H}_{1}\right)$ diterima. Artinya ada pengaruh antara variabel Pendapatan ASli Daerah terhadap Kinerja Keuangan Pemerintah Daerah.

\section{Pengujian pengaruh Dana Perimbangan terhadap Kinerja Keuangan Pemerintah Daerah}

Hasil uji hipotesis variabel Dana Perimbangan menggunakan tingkat signifikansi $\alpha=5 \%$ diperoleh $p$-value sebesar 0,018 dimana lebih kecil dari $\alpha 0,05$ yang berarti hipotesis kedua $\left(\mathrm{H}_{2}\right)$ ditolak. Artinya ada pengaruh antara variabel Dana Perimbangan terhadap Kinerja Keuangan Pemerintah Daerah.

\section{Uji Koefisien Determinasi $\left(\mathbf{R}^{2}\right)$}

Berikut ini adalah tabel hasil pengolahan data koefisien determinasi: 


\section{Hasil Uji Koefisien Determinasi $\left(\mathbf{R}^{2}\right)$}

\begin{tabular}{|l|l|l|l|l|}
\hline & $\mathrm{R}$ & R Square & Adjusted R Square & $\begin{array}{l}\text { Std. Error of the } \\
\text { Estimate }\end{array}$ \\
\hline 1 & $.547^{\mathrm{a}}$ & .299 & .253 & .20624 \\
\hline
\end{tabular}

a. Predictors: (Constant), LOG10PAD, LOG10DP

b. Dependent Variable: LOG10KKPD

Sumber : Data sekunder yang diolah, 2017

Berdasarkan tabel menunjukkan bahwa nilai Adjusted R-Square sebesar 0,253 atau 25,3\%. Maka dapat disimpulkan bahwa Pendapatan Asli Daerah dan Dana Perimbangan berpengaruh sebesar 25,3\% terhadap Kinerja keuangan Pemerintah Daerah sedangkan sisanya $74.7 \%$ dipengaruhi oleh faktor yang tidak diteliti dalam penelitian ini.

\section{PEMBAHASAN}

\section{Pengaruh PAD terhadap Kinerja Keuangan Pemerintah Daerah}

PAD sebagai komponen utama dari penerimaan daerah akan sangat menentukan besaran alokasi belanja. Nilai koefisien regresi PAD bernilai positif ini dapat diartikan bahwa dengan adanya peningkatan PAD dapat meningkatkan Kinerja Keuangan Pemerintah Daerah di Provinsi Jawa Barat.

Pendapatan Asli Daerah adalah pendapatan yang berasal dari potensi asli daerah sesuai dengan peraturan yang berlaku yang dapat dikenakan kepada setiap wajib pajak. Peningkatan PAD akan mengakibatkan peningkatan kinerja keuangan pemerintah. Hal ini dapat terjadi karena Pemerintah Kabupaten dan kota di Provinsi Jawa Barat menekankan hasil atas PAD mereka berasal dari berbagai sumber yang dikelola oleh daerah dalam bentuk penerimaan pajak, retribusi dan penerimaan lainnya yang sah yang diatur dalam Undang- Undang.

Hasil penelitian ini mendukung hasil penelitian Julitawati dkk. (2012) dan Wenny (2012) yang menyatakan bahwa Pendapatan Asli Daerah berpengaruh terhadap Kinerja Keuangan Pemerintah Daerah. Artinya Pendapatan Asli Daerah sangat mempengaruhi Kinerja Keuangan Pemerintah Daerah sesuai dengan prinsip otonomi daerah. 


\section{Pengaruh Dana Perimbangan terhadap Kinerja Keuangan Pemerintah Daerah}

Dana Perimbangan sebagai komponen utama dari penerimaan daerah akan sangat menentukan besaran alokasi belanja. Nilai koefisien regresi Dana Perimbangan bernilai negatif ini dapat diartikan bahwa kenaikan Dana Perimbangan mengurangi jumlah dana yang dapat dialokasikan untuk membiayai proyek atau kegiatan Pemerintah Daerah.

Berpengaruhnya Dana Perimbangan terhadap Kinerja Keuangan Pemerintah Daerah menunjukkan bahwa pemerintah daerah di Jawa Barat sudah mulai mampu mengelola secara maksimal dana yang ditransfer dari Pemerintah Pusat.

Hasil penelitian ini mendukung hasil penelitian Cinthya (2012) yang menyatakan bahwa Dana Perimbangan berpengaruh terhadap Kinerja Keuangan Pemerintah Kabupaten Bantul. Artinya pemerintah sudah bisa mengoptimalkan Dana Perimbangan.

\section{SIMPULAN dan SARAN}

\section{Simpulan}

Berdasarkan hasil analisis dan pembahasan yang telah dilakukan maka diperoleh kesimpulan bahwa Pendapatan Asli Daerah (PAD) berpengaruh terhadap Kinerja Keuangan Pemerintah Daerah berarti H1 diterima. Artinya dengan adanya peningkatan PAD dapat meningkatkan Kinerja Keuangan Pemerintah Daerah di Provinsi Jawa Barat. Dana Perimbangan berpengaruh terhadap Kinerja KeuanganPemerintah Daerah berarti H2 diterima. Artinya bahwa Pemerintah Daerah sudah mulai mampu mengelola secara maksimal dana yang ditransfer dari Pemerintah Pusat.

\section{Saran}

Penulis menyarankan agar peneliti selanjutnya dapat menambah periode tahun anggaran tidak hanya 3 tahun sehingga dapat diperoleh hasil yang lebih komprehensif dan diketahui perbandingan dari tahun ke tahun. Kedua, diharapkan dapat menambahkan variabel-variabel lain yang dapat berpengaruh terhadap Kinerja Keuangan Pemerintah Daerah Kabupaten dan Kota seperti sumber lain-lain pendapatan yang sah, 
Belanja Operasi, dan Pembiayaan. Ketiga, penelitian selanjutnya diharapkan tidak hanya menggunakan data sekunder saja, hendaknya melakukan konfirmasi langsung pada daerah yang menjadi objek penelitian.

\section{DAFTAR PUSTAKA}

,UU No. 17 Tahun 2003 tentang Keuangan Negara

,UU No. 1 Tahun 2004 tentang Perbendaharaan Negara

,UU No 15 Tahun 2004 tentang Pemeriksaan Pengelolaan dan

Tanggungjawab Keuangan Negara.

Mardiasmo. 2004. Akuntansi Sektor Publik. Yogyakarta: Andi

Mardiasmo. 2002. Otonomi dan Manajemen Keuangan Daerah. Yogyakarta: Andi

Halim, Abdul. 2001. Manajemen Keuangan Daerah. Yogyakarta: UPP AMP. YKPN

Halim, Abdul. 2007. Akuntansi Sektor Publik: Akuntansi Keuangan Daerah. Jakarta: Edisi 3, Salemba Empat

Halim, Abdul. 2008. Akuntansi Keuangan Daerah, Akuntansi Sektor Publik. Jakarta: Salemba Empat.

Halim, Abdul. 2001. Manajemen Keuangan Daerah. Yogyakarta: UPP AMP. YKPN.

Mahsun, M. 2006. Pengukuran Kinerja Sektor Publik. Yogyakarta: BPFE.

Sugiyono. 2012. Metode penelitian Kuantitatif Kualitatif dan R\&D. Bandung: Alfabeta

Bastian, Indra. 2010. Akuntansi Sektor Publik: Suatu Pengantar. Jakarta: Erlangga

Mariani, Lidia. 2013. Analisis Kinerja Keuangan Pemerintah Daerah Sesudah Pemekaran Daerah. Artikel Ilmiah Program Studi Akuntansi, Fakultas Ekonomi, Universitas Negeri Padang

Damanhuri, Zulkifly Prabowo. ... Analisa Kinerja Keuangan Pemerintah Kota di Jawa Timur Tahun Anggaran 2007-2011. Jurnal Fakultas Ekonomi dan Bisnis Universitas Brawijaya Malang.

Ulum, Ihyaul. 2005. Akuntansi Sektor Publik: Sebuah Pengantar. Malang: UMM Press. 
Bisma dan Susanto. 2010. Evaluasi Kinerja Keuangan Daerah Pemerintah Provinsi Nusa Tenggara Barat Tahun Anggaran 2003-2007. GaneÇ Swara, Vol. 4, No.3, Desember 2010.

Wahyuni, Nanik. ... Analisis Rasio Untuk Mengukur Kinerja Pengelolaan Keuangan Daerah Kota Malang. Jurnal Akuntansi Fakultas Ekonomi UIN Maliki Malang. 